\title{
STUDY ON SWEETENER SELECTION IN RTD TEA BEVERAGES
}

\author{
[Studi Pemilihan Pemanis Pada Teh Siap Minum]
}

\author{
Hendry Noer Fadlillah ${ }^{1,3)}$, Hari Sakti Ramadhan ${ }^{2)}$, Joko Hermanianto ${ }^{2)}$, and Lira Felanesa ${ }^{3)}$ \\ 1) Department of Food Technology, Faculty of Life Science, International Uni versity Liaison Indonesia (IULI), Tangerang \\ 2) Department of Food Science and Technology, Faculty of Agriculture Technology, Bogor Agricultural University, Bogor \\ 3) PT INAVIGA Indonesia, Bogor
}

Received March $3^{\text {rd }} 2018$ / Accepted December $20^{\text {th }} 2019$

\begin{abstract}
Tea beverages are getting more popular in Indonesian market. Today, consumers can find tea beverage products in many variants, including ready to drink (RTD) tea beverages. One of the most importantingredient in tea beverages is sugar that provides sweet taste. Due to the increasing concerns on the risk of diabetes mellitus type 2, the Indonesian government has campaigned to reduce sugar consumption. This research purposes were to understand and analyze the type of sweeteners in RTD tea beverages and the producer strategy in reducing sugar. The study was conducted by collecting available RTD tea beverages in modern retail shops. All ingredients on the label was recorded then the correlation with other information on the label and regulation was analyzed. The results showed that all of the sweetened RTD tea beverages ( $n=58)$ use sucrose as the sweetener. Sucrose was used singly $(81 \%)$ or in combination (17\%) with other sweeteners. Most RTD tea beverages $(60 \%)$ used sucralose in combination with sucrose. Others used steviol glycoside $(20 \%)$ and fructose $(20 \%)$. There were $24 \%$ of the RTD tea beverages that provides claim, $64 \%$ of the claim was regarding sugar and calorie. Based on the correlation analysis, it was concluded the tea beverage producers use three strategy in reducing calorie and sugar content in their products, i.e. by 1) totally removing the sugar content, 2) reducing the sweetness level, or 3) combining sucrose with high intense sweetener.
\end{abstract}

Keywords: fructose, RTD tea, steviol glycoside, sucralose, sweetener

\begin{abstract}
ABSTRAK
Minuman teh saat ini sangat populer di pasar Indonesia. Konsumen dapat menemukan produk minuman teh dalam berbagai varian, termasuk teh siap minum (ready to drink, RTD). Salah satu bahan terpenting dalam teh adalah gula yang fungsi utamanya memberikan rasa manis. Saat ini perhatian terhadap risiko diab etes mellitus tipe 2 semakin meningkat. Oleh sebab itu, pemerintah telah berkampanye untuk mengurangi konsumsi gula. Penelitian ini dilakukan untuk mengetahui jenis pemanis dan strategi produsen dalam mengurangigula pada minuman teh RTD. Penelitian ini dilakukan dengan mengumpulkan produk teh RTD yang tersedia di pasar ritel modern. Semua bahan yang tercantum dalam daftar komposisi pada label dicatatkemudian dianalisis untuk mengetahui korelasi dengan informasi lain yang terdapat pada label dan regulasi. Hasil penelitian menunjukkan bahwa semua teh RTD manis menggunakan sukrosa dalam komposisinya. Sukrosa digunakan baik secara tunggal (81\%) maupun kombinasi (17\%) dengan pemanis lainnya. Untuk kombinasi, sebagian besar teh RTD (60\%) menggunakan sukralosa, sedangkan lainnya menggunakan glikosida steviol (20\%), dan fruktosa (20\%). Selain itu sebanyak $24 \%$ teh RTD memiliki klaim dalam labelnya, dan 64\% dari klaim tersebut adalah terkait dengan gula dan kalori. Berdasarkan analisis korelasi, dapat disimpulkan bahwa produsen menggunakan tiga strategi dalam mengurangi kalori dan kadar gula dalam produknya, yaitu dengan 1) menghilangkan gula secara keseluruhan, 2) mengurangi tingkat kemanisan, atau 3) mengombinasikan sukrosa dengan pemanis lainnya.
\end{abstract}

Kata kunci: fruktosa, pemanis, steviol glikosida, sukralosa, teh siap minum

The manuscript has been presented at Seafast International Seminar, Current and Emerging Issues of Food Safety: Innovation Challenges, November 20-21 2017 , Bogor-Indonesia *Corresponding Author: E-mail: hendry.nf@gmail.com 


\section{INTRODUCTION}

Tea commodity has important role for Indonesia economic growth. Nationally, tea industries contributed Rp. 1.2 trillion to GDP (Gross Domestic Product) and USD 110 million to foreign exchange (Kementan, 2015). Euromonitor (2017) stated, tea is very famous and well consumed in Indonesia. Tea was remained highly competitive in 2016 with many players, both national and multinational companies. One of the most famous products is ready to drink (RTD) tea beverage. RTD tea beverage is very popular because of its convenience, in addition its fresh taste and flavor. Euromonitor (2017) predicted RTD tea beverage to record a strong growth and reach volume CAGR of $6 \%$ over the forecast period. Many activities in pack sizes to address affordability for on-the-go consumers, as well as launches of new flavors, especially those linked with healthier tea variants, will help to increase the market of these already popular soft drinks amongst Indonesian consumers. Based on Kantar Worldpanel Indonesia research (2014), RTD tea beverage is the most out of home purchase for respondents in the age range of 11-20 years old (teenagers), 21-30 years old (young adult), and above 30 years old (adult).

Indonesians like sweetened tea. The source of sweet taste in tea mostly from sugar, which is contribute to the calorie intake. There is contribution of consumption of sugar-sweetened soft drink, including RTD tea beverage, to the weight gain. Sugar from the beverages together with other foods will increase the calorie. The balance of calorie intake is needed to maintain ideal weight. Not ideal body weight can increase the risk of health problems. Intake of free sugar from food consumption should be reduced both in children and adults. Contribution of calorie from free sugars is recommended to be less than $10 \%$ of total energy intake (WHO, 2015). In Indonesia, government also recommends intakes of sugar below $50 \mathrm{~g}$ per day. Based on the Total Diet Study in 2014, it is estimated that there is $11.8 \%$ of the Indonesian population consumed more than recommended sugar intake per day. Sources of sugar can come from various types of food consumed daily such as table sugar, sweetened drinks, snack, candies, chocolate products, and other processed foods (Atmarita et al., 2018). Through Health Minister Regulation No. 30 (2014), Government regulates food industries to inform the content of sugar, salt, and fat in their products and put healthy message on the label.

There is a need to reduce the intake of sugar. The industries response and strategy to answer the need can be monitored by label identification, because regulation require food industries to put the sugar content information, ingredient list, and claim on packaging label. The industries response could be by sugar replacement or provide claim regarding sugar or calorie reduction. The purposes of this research were to identify the sweetener selection in RTD tea beverage, analyze the response of industries and strategy to reduce sugar in RTD tea beverage, identify the type of claim in RTD tea beverage, and to understand the correlation between the claim and sweetener selection in RTD tea beverage formulation.

\section{MATERIALS AND METHODS}

\section{Materials}

Materials used for this research were RTD tea products from modern retail. Regulation documents, such as Regulation of the Minister of health for food additive and some technical regulation of Indonesia National Agency of Drug and Food Control (NADFC) for food category, claim, food additive, and others were also used to identify label information.

\section{Methods}

RTD tea products were collected from the modern retail in Bogor Indonesia. All of the information on the label of products were recorded and categorized based on the regulation. Type of RTD tea beverage was classified by Regulation of Head of NADFC No. 21 (2016) for Food Category; Claim information was classified based on regulation of NADFC No. 13 (2016) for Claim Supervision on Label and Advertising of Processed Food; Food additive was identified by using regulation of Minister of health for food additive; and Sweetener food additive was classified by using Regulation of Head of NADFC No. 4 (2016) about Maximum Limit of Food Additive Sweetener Usage. After all information classified, then they were analyzed statistically by using Microsoft Excel to understand the correlation of each other.

\section{RESULT AND DISCUSSION}

\section{Classification of RTD tea beverages}

Ready to drink tea industry in Indonesia is currently growing rapidly (Thamrin et al., 2016). Ready to drink tea (RTD) is defined as drink of tea leaves or extracts tea in drinking water with the addition of sugar and packaged hermetically (BPOM, 2016a). BPOM (2016b) classify tea drink into some group based on the process. The classification includes tea, green tea, white tea, oolong tea, jasmine tea, and others. Based on BPOM data (2018), there are many variants of RTD tea beverages, but not all available in modern retail. Survey in modern retail show there are 60 variants of RTD tea beverages. 
Black tea and jasmine tea dominate type of RTD tea beverages in market (Figure 1).

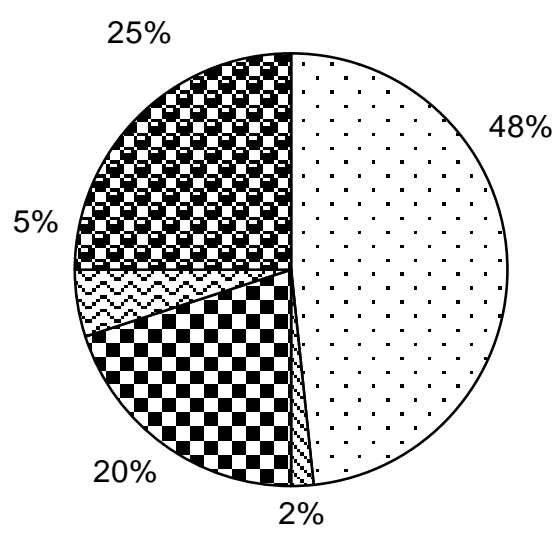

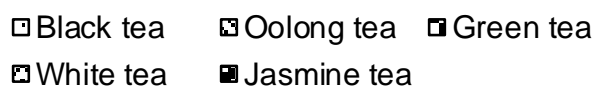

Figure 1. Tea variants in modern market

Black tea is defined as tea from shoots or young leaves, which include its stalk, from tea plants (Camellia sinensi L.) and processed through fermentation. Jasmine tea is processed tea with addition of jasmine flower (Jasminum sambac), gambir jasmine flower (Jasminum officinale), culan flower (Aglia odorata) or its extract (BPOM, 2016b). Meriza et al. (2016) stated black tea is the most consumed RTD tea beverage type in Indonesia house hold because of its taste. The industries also produce tea with the taste black tea, green tea, and jasmine tea as their major variants. Nugraha et al. (2017) also reported black tea has some excellences attributes, such as taste and aroma. Meriza et al. (2016) reported taste as the most important attribute for Indonesia consumers.

Producers launch many kinds of tea flavors to attract consumer (Euromonitor, 2017). Each type of tea provides different character of flavor. Flavor has important role to influence tea consumer preferences (Jeevitha et al., 2016). Each producer has own uniqeness. Different production process yields। tea product with different characteristics in flavor and sensory properties. The composition of tea chemical, including volatile and aromatic compounds is influenced by process and raw material. For example, fermentation process increases the level of terpenoids, aromatics, and aliphatic compounds. Because of this reason, oolong tea has highest in jasmine lactone (Baldermann et al., 2014).

Besides the taste, consumers are increasingly demanding healthier and safer food products, including soft drink products such as tea (Horská et al., 2011). One of the health problems concern in In- donesia are obesity and diabetes. Currently, Indonesia Government estimated 1.2-2.3\% prevalence of obesity among people over 15 years (Sutanegara and Budhiarta, 2000). The diabetes mellitus prevalence for productive age in urban area was $4.6 \%$ of population. The value includes $1.1 \%$ previously diagnosed diabetes mellitus and 3.5\% undiagnosed diabetes (Mihardja et al., 2014). Data from National survey predicts the number of diabetes prevelance increased to $5.7 \%$, which is more than $70 \%$ cases were undiagnosed (Soewondo et al., 2013). Ministry of Health stated one of the causes of health problems is high sugar consumption, including through beverages. Sugar sweetened beverages contribute to the epidemic of obesity and overweight. Therefore, through Guideline of balanced nutrition, the government encourages people to reduce and limit sugar consumption (Kemenkes, 2011).

\section{Sweetener selection in RTD tea beverages}

Most of RTD tea beverage in modern retail is sweetened tea. There are $98 \%$ variants of the product belong to sweetened RTD tea. Taste is significant parameter for tea consumers. Tastes that tea consumers most consider are sweet and bitter (Aprilliani, 2013). Rahmasari et al. (2017) stated that sweet taste and jasmine aroma are considered as representative of the typical Indonesian tea character. The preference for sweet taste is both natural and universal. Yolanda et al. (2017) stated there was no difference threshold of sweetness of tea between individuals with and without family diabetic history. Both have a higher sugar intake than recommended. The pleasure response to sweet taste is observed across individuals of all ages, races, and cultures. It is basic biology that dictates a liking for sweetness across the lifespan (Drewnowski et al., 2012). So it is logic, if taste becomes the most important attribute in choosing tea.

There are two groups of sweeteners, firstly is sweetener that used in large quantities or bulk sweetener, and secondly is intense sweetener that usually used in very small quantities (Burgos et al., 2016). Sucrose is still being most favourite for the sweetened RTD tea beverages. All of them use sucrose as sweetener, either in a single addition or in blending with other sweeteners (Figure 2a). Sucrose is the common ingredient used to sweeten soft drink, including RTD tea beverages (Ban et al., 2017). The research by comparing fructose and aspartame result no significant difference, but when compared to the sucrose, both fructose and aspartame have significantly lower rating regarding preference level to sucrose. There are challenge in after taste when use other sweeteners. The after taste of the product tends to the bitter and unpleasant. Because of that reason, producer should solve the problem by conducting reformulation. The problem is 
not only sugar replacement, but also reformulation of low calorie sweetener with other ingredients to get acceptable level of products. Walker et al. (2014) also reported that there is different sensory profile of beverage with fructose and sugar with sucrose in formulation.

Another challenge is regarding the safety issues. The approved sweeteners have passed scientific study on food safety, but there is still consumers concerns to the safety that it may be an inhibiting factor to the development of artificial sweeteners (Shrapnel, 2015). Though, the addition of noncaloric sweetener will open new avenues in the food industries as an alternative source of sucrose (Verma and Singh, 2014).

\section{Sweetener combination}

Sweetener combination is a choice in food products formulation. The food industries attempt to reduce sugar and calorie content in their products. The challenge is most of alternative sweetener exhibit undesirable off tastes (Beltrami et al., 2018). Combination among the sweetener can be an answer to solve the problem, so food industries are able to reduce the sugar or calorie, and still maintain the taste quality. In a beverage, the addition of sucrose is still important for the acceptance of flavor attribute. Replacement of sucrose for 20 and $40 \%$ by rebaudioside A showed very similar sensory profile in a model beverage. So, there is still sweetener blending in formulation (Majchrzak et al., 2015). Formulating beverages with stevia provide some challenges in high sweetness level, sweetness linger, and a strong aftertaste. Blending of steviol glycosides with other sweetener (such as sucrose and fructose) enables optimal taste with clean, superior, sugar-like taste, and reduced lingering taste (PureCircle Stevia Institute, 2018a).

There are two categories of sugar substitutes or replacement. Firstly is natural sweetener, and secondly is artificial sweetener. Sugar substitute is alternative to sweeten foods and beverages with less calorie and energy compare to sucrose (Jain and Grover, 2015). BPOM regulates food additive sweetener through Peraturan Kepala Badan POM No. 4 (2014) tentang Batas Maksimum Penggunaan Bahan Tambahan Pangan Pemanis (Regulation of Head of BPOM No. 4, 2014, about Maximum Limit of Sweetener Food Additive). In that regulation, sweetener is defined as food additive, both natural and artificial sweetener, to provide sweet taste to food products. Natural sweetener is sweetener that can be found in natural material, although the process through synthetic or fermentation. Artificial sweetener is chemically processed sweetener, and it cannot be found in natural material.

The replacement of sucrose with sugar substitute will help producer to lower the calorie of their products. It can be added in small amount to provide same level sweetness of sugar. So, it is also known as high intensity sweetener. This sweetener is actually to respon consumer demand to less calorie products for healthier life style. For the RTD tea beverages, there are three kinds of sweetener which is used in combination with sucrose. Fructose is mostly used as alternative sweetener, then sucralose and steviol glycoside (Figure 2b). Fructose is not food additive, but classified as raw material. Sucralose is classified as artificial sweetener food additive, and steviol glycoside is in natural sweetener food additive (BPOM, 2014).

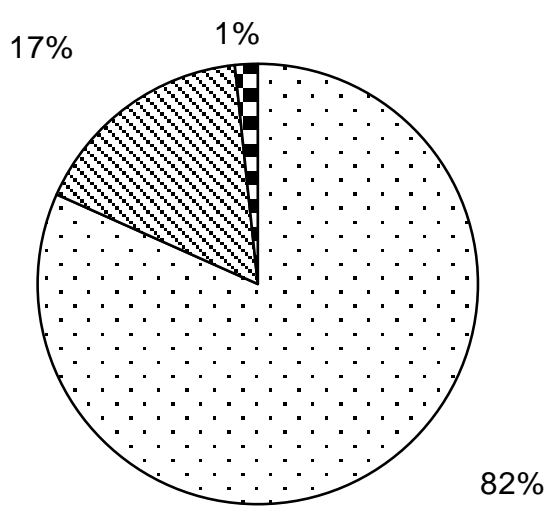

$\square$ Only sucrose

$₫$ Sucrose + other sweetener $\square$ No sweetener

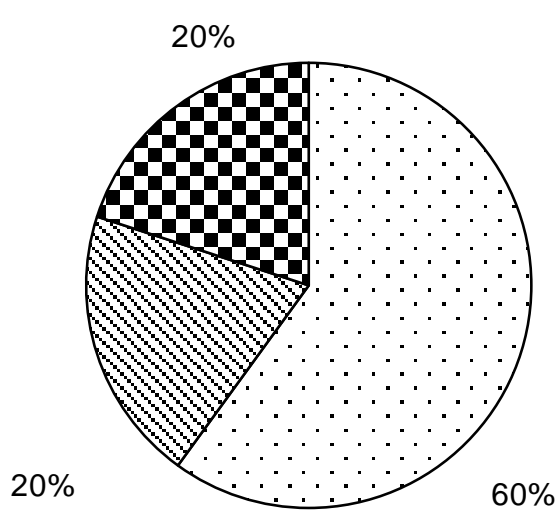

$\square$ Fructose $\mathbf{Q}$ Sucralose $\boldsymbol{\nabla}$ Steviol glycoside

Figure 2. Type of sweeteners used in RTD tea beverages (A). Other sweeteners which are used in combination with sucrose (B)

Fructose actually is natural sweetener. It can be found naturally in most of the fruits. Burgos et al. 
(2016) stated the calorie content of fructose actually similar to other types of sugar in similar amount. But, the sweetness level of fructose is higher. So by using less fructose, producer can get same level of sweetness with sucrose. Van Buul et al. (2014) reported that there is insufficient data to demonstrate that fructose have a role in metabolic disease and the global obesity epidemic, so it can be used to reduce calorie in food products. White et al. (2015) also confirmed that fructose is used in soft drink. Fructose is very popular in soft drink formulation (Walker et al., 2014). In formulation, fructose provide advantages when combine with sucrose or sucralose. Combination of fructose and sucrose can enhance the sweetness level of the product. If combined with sucralose, fructose can also reduce the total sweeteners than used alone. Besides reduce calorie content, fructose is also claimed to provide other advantages, such as to lower glycemic response, improve humectancy and extends shelf life, easy to use, and easy to handle (Tate and Lyle, 2017a).

Tejo et al. (2013) stated as a natural sweetener stevia is actually a perfect alternative to replace sugar. Steviol glycoside is a chemical from stevia that approved to be used as sweetener in Indonesia. Stevia is very popular, because of their second metabolite, steviol glycoside. This metabolite is responsible to the sweetness level of stevia leaf. The level of stevia sweetness is claimed 250-300 times higher than sugar (PureCircle Stavie Institute, 2018a). Steviol glycoside is already approved as natural sweetener food additive in Indonesia (BPOM, 2014). This sweetener is expected to be effective alternative to sugar in many products, including beverages. Steviol glycoside can be formulated in blending with other sweetener to give synergistic effect on sweetness and stability. The addition of steviol glycoside for beverage products provides some benefits, because its properties such as $\mathrm{pH}$ stable, non fermenting, highly soluble, and shelf stable. Beside impact to the sweetness, steviol glycoside also can act as flavor modifier. Combination of steviol glycoside in RTD tea beverage provides clean sweetness profile by reducing astringency and bitterness. It also reduce sugar up to $50 \%$ in tea sample (PureCircle Stavie Institute, 2018b).

Sucralose or trichologalactosucrose is artificial sweeteners. The sweetness level is claimed until 600 times of sugar, and no calorie. This sweetener also provides excellent taste profile and blends well with other type of sweeteners. In addition, sucralose is also able to reduce cost in formulation (Tate and Lyle, 2017b).

\section{Claim in RTD tea beverages}

Food industries can put claim for their products for the several conditions. Claim is defined as any descriptions that suggests or indirectly states the specific characteristics of a food relating to the origin, nutritional content, properties, production, processing, composition, or other quality factors. There are some types of claim, such as nutrition claim, health claim, nutrient content claim, nutrient comparative claim, nutrient function claim, and other function claim (BPOM, 2016b).

Tea has been known to have health benefits, and $24 \%$ of RTD tea beverage provides nutritionalrelated claims or nutrient comparisons. In order to provide a claim the producer must register it to the BPOM by enclosing complete scientific evidence (BPOM, 2016b). Most of respondent awared to the information on label to evaluate and make decision in product selection. One of the influential information is nutrition content claim (Roy Morgan Research, 2008). Fadlillah et al. (2015) reported that claim is in first ranked read by consumers aged 1524 years. Different opinion happened to consumers over the age of 24 years, where health claims are in ranked seventh. Patterson et al. (2012) stated a good awareness of product claim. However, it is different if we talk about the level of calorie or sugar reduction. There is a little awareness of the level of sugar or calorie reduction. There is also confusion understanding around calorie content of different nutrients. It is important for food industries and government to educate consumers about the claim definition.

Based on the investigation, claims of less sugar/no sugar/low calorie were mostly used for RTD tea beverages. The other claims are EGCG added and high vitamin C (Figure 3). Table 1 show that there are some claims in RTD tea beverages regarding energy and sugar content.

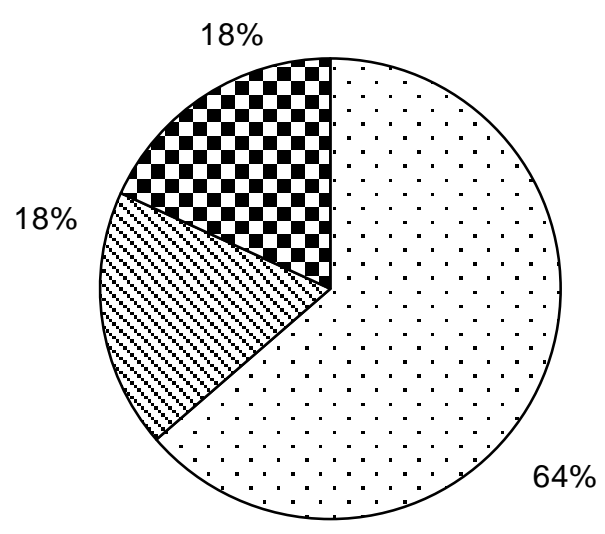

$\square$ Less sugar/no sugar/low calorie $\triangle E G C G$ added

घHigh vitamin C

Figure 3. Claims in RTD tea beverages 
Table 1. Calorie value in claimed sweetened tea

\begin{tabular}{|c|c|c|c|}
\hline Component & Claim & Calorie Requirement ${ }^{*}$ & Calorie in Label \\
\hline \multirow[t]{2}{*}{ Energy } & Low & $\begin{array}{l}\text { No more than: } \\
\text { - } 40 \text { kkal }(170 \mathrm{~kJ}) \text { per } 100 \mathrm{~g} \text { (in solid product) } \\
\text { or } \\
\text { - } 20 \mathrm{kkal}(80 \mathrm{~kJ}) \text { per } 100 \mathrm{~mL} \text { (in liquid } \\
\quad \text { product) }\end{array}$ & $18-20 \mathrm{kkal} / 100 \mathrm{~mL}$ \\
\hline & Free & $\begin{array}{l}\text { No more than: } \\
-4 \text { kkal per } 100 \mathrm{~g} \text { (in solid product) or } \\
-4 \text { kkal per } 100 \mathrm{~mL} \text { (in liquid product) }\end{array}$ & (No sample) \\
\hline \multirow[t]{3}{*}{ Sugar } & Less & $\begin{array}{l}\text { Product is new formulation. } \\
\text { Compared with similar processed food } \\
\text { products from the same manufacturer, the } \\
\text { content of nutrient comparasion is lower or } \\
\text { higher }\end{array}$ & $4-5.67 \mathrm{~g} / 100 \mathrm{~mL}$ \\
\hline & Low & $\begin{array}{l}\text { No more than: } \\
-5 \mathrm{~g} \text { per } 100 \mathrm{~g} \text { (in solid product) or } \\
-\quad 2.5 \mathrm{~g} \text { per } 100 \mathrm{~mL} \text { (in liquid product) } \\
\end{array}$ & (No sample) \\
\hline & Free & $\begin{array}{l}\text { No more than: } \\
-\quad 0.5 \mathrm{~g} \text { per } 100 \mathrm{~g} \text { (in solid product) or } \\
-\quad 0.5 \mathrm{~g} \text { per } 100 \mathrm{~mL} \text { (in liquid product) } \\
\end{array}$ & $0 \mathrm{mg} / 100 \mathrm{~mL}$ \\
\hline
\end{tabular}

Firstly is claim of nutrient content. Claim of nutrient content means claim that describe the content of nutrient in food products.

There are RTD tea beverages with low energy claim. Based on BPOM (2016b), low energy claim must have calorie no more than $20 \mathrm{kkal}$ per $100 \mathrm{~mL}$ for liquid product. In fact, the RTD tea beverages with that claim, contain calorie range from 18 $\mathrm{kkal} / 100 \mathrm{~mL}$ to $20 \mathrm{kkal} / 100 \mathrm{~mL}$. That means, they meet regulation requirement. Other type of claim regarding sugar is nutrient comparative claim. Claim of nutrient comparative is claim that compare nutrient content or energy between two products or more.

This nutrient comparative claim in RTD tea beverage is less sugar claim. Some of RTD tea beverages compare their sugar content to other products to claim that they have lower sugar. The calorie for this type claimed products range 4.00-5.67 g/100 $\mathrm{mL}$. Less sugar claim can be a choice to be considered by consumers if they want fewer sugar intake when consuming RTD tea beverage.

Interestingly, products that have low-calorie or less sugar claims still use sugar. They use sucrose as sweetener. Some of them only use sucrose and other in combination with other sweetener. It means, some of the products reduce the sweetness level, because there is no other sweetener addition to replace the sugar reduction in formulation. Others still maintain the sweetness level by adding the sweetener food additive. Total of 78\% RTD tea beverage with less sugar/low calorie claims still use sucrose in a single form. However, when viewed on the label, the calorie value per serving is still lower than the RTD tea product without low calorie claims. There is $22 \%$ of RTD tea beverages with low sugar/ low calorie claim combines sugar and other sweeteners (Figure 4).

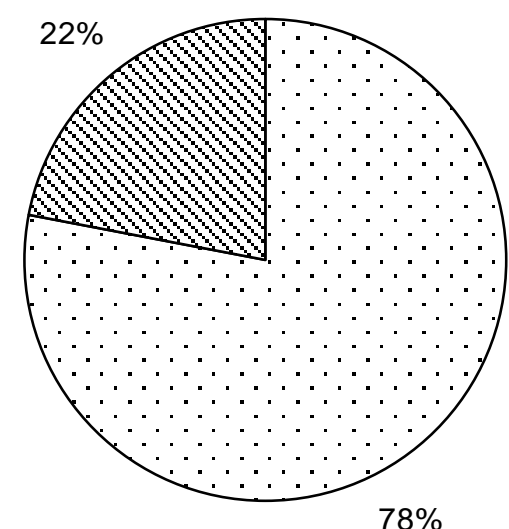

$\square$ Only sucrose

$\checkmark$ Combine with other sweeteners

Figure 4. The type of sweetener use in claimed sweetened tea

Not all RTD tea products that use sugar replacers have low calorie or less sugar claim. It means, addition of sugar replacers is not only regarding on claim or calorie/sugar reduction. Other purposes of the use of sugar replacer can be related to cost or price, technological aspect, sensory quality, and others.

Sucrose in soft drink, including tea, in addition to giving a sweet taste, it also has other roles. Therefore, some manufacturers still use sugar in the formulations. Sugar has significant function both in 
sensory parameter and safety factor of beverages. Sugar together with acidulant provides basic taste profile in soft drinks. Another function of sugar is as bulking agent to make a body in the product. The addition of sugar also reduces water activity that will minimize microbial growth. So, the function of sugar is not only as sweetener, but more than that (Burgos et al., 2016).

\section{CONCLUSION}

To reduce the risk of cardiovascular disease and diabetes, the Government has recommended to reduce the consumption of sugar in various food products, including beverages. Tea is one of the favorite drinks in Indonesia. To answer the Government's recommendation to lower sugar intake, some RTD tea producers have produced their products with low-calorie, low-sugar, and even non-sugar claims.

However, for products which low-sugar or lowcalorie claim, they still use sucrose in their formulations, either singly or by combining with other sweeteners, they are fructose, sucralose, and steviol glycoside. This means that there are three formulation strategies to produce low-calorie or low-sugar products. Firstly is by removing the sugar content totally, so there is no sweetness in the tea product. Secondly is by lowering the level of sugar use, so the sweetness remains, but with a lower level. Thirdly is by combining sugar with other sweeteners, so the calories become lower, but the level of sweetness is still maintained.

\section{REFERENCES}

Aprilliani K. 2013. Analisis Sikap Konsumen terhadap Teh Pucuk Harum di Kota Bogor [Skripsi]. Bogor: Fakultas Ekonomi dan Manajemen, Institut Pertanian Bogor.

Atmarita, Imanningsih $\mathrm{N}$, Jahari $\mathrm{AB}$, Permaesih $\mathrm{D}$, Chan P, Amarra MS. 2018. Consumption and sources of added sugar in Indonesia - a review. Asia Pasific J Clin Nutr 27: 47-64 DOI: 10.6133/ apjcn.042017.07.

Baldermann S, Yang Z, Katsuno T, Anh Tu V, Mase N, Nakamura Y, Watanabe N. 2014. Discrimination of green, oolong, and black teas by GCMS analysis of characteristic volatile flavor compounds. Am J Analytic Chem 5: 620-632. DOI: 10.4236/ajac.2014.59070.

Ban Q, Wang X, Pan C, Wang Y, Kong L, Jiang $H$. 2017. Comparative analysis of the response and gene regulation in cold resistant and susceptible tea plants. PLoS ONE 12: e0188514. DOI: $10.1371 /$ journal.pone. 0188514 .
Beltrami MC, Döring T, Lindner JDD. 2018. Sweetener and sweet taste enhancers in the food industry. J Food Sci Technol 38: 181-187 DOI: 10.1590/fst.31117.

[BPOM] Badan Pengawas Obat dan Makanan. 2014. Peraturan Kepala Badan POM RI No. 4 tahun 2014 tentang Batas Maksimum Penggunaan Bahan Tambahan Pangan Pemanis. BPOM, Jakarta.

[BPOM] Badan Pengawas Obat dan Makanan. 2016a. Peraturan Kepala Badan POM RI No. 21 tahun 2016 tentang Kategori Pangan. BPOM, Jakarta.

[BPOM] Badan Pengawas Obat dan Makanan. 2016b. Peraturan Kepala Badan POM RI No. 13 tahun 2016 tentang Pengawasan Klaim pada Label dan Iklan Pangan. BPOM, Jakarta.

[BPOM] Badan Pengawas Obat dan Makanan. 2018. Cek produk BPOM. http://cekbpom.pom.go.id/ index.php/home/produk/m9r4p7sihm5Int4grdjr3 pveh5/all/row/10/page/1/order/4/DESC/search/1 /teh [September $3^{\text {th }} 2018$ ].

Burgos K, Subramaniam P, Arthur J. 2016. Reformulation guide spotlight on sugars for small to medium size companies. Food and Drink Federation. https://www.fdf.org.uk/corporate_pubs /Reformulation-Guide-Sugars-Aug2016.pdf [January $19^{\text {th }} 2018$ ].

Drewnowski A, Mennella JA, Johnsoh SL, Bellisle F. 2012. Sweetness and food preference. J Nutr 142: 1142S-1148S. DOI: 10.3945/jn.111.1495 75.

Euromonitor. 2017. Tea in Indonesia. http://www. euromonitor.com/tea-in-indonesia/report [October $\left.24^{\text {th }} 2017\right]$.

Euromonitor. 2017. RTD tea in Indonesia http://w ww.euromonitor.com/rtd-tea-in-indonesia/report [October $24^{\text {th }} 2017$ ].

Fadlillah HN, Nuraida L, Purnomo EH. 2015. Kepedulian konsumen terhadap label dan informasi bahan tambahan pangan (BTP) pada label kemasan pangan di Kota Bogor. J Mutu Pangan 2: 119-126.

Horská E, Ürgeová J, Prokeinová R. 2011. Consumers' food choice and quality perception: Comparative analysis of selected Central European countries. Agric Econ-Czech 57: 493-499. DOI: 10.17221/103/2011-AGRICECON.

Jain T, Grover K. 2015. Sweeteners in human nutrition. Int J Health Sci Res 5: 439-451.

Jeevitha RS, Monisha S, Morsawala SN, Gowthamlal $\mathrm{NRH}$, Ganesh BCP. 2016. A study of change in consumer preferences from the conventional hot beverages to green tea. EPRA Int J Economic Business Rev 4: 185-194. 
[Kemenkes] Kementerian Kesehatan. 2011. Strategi Nasional Penerapan Pola Konsumsi Makanan dan Aktivitas Fisik untuk Mencegah Penyakit Tidak Menular. Direktorat Jenderal Bina Gizi dan Kesehatan Ibu dan Anak Kementerian Kesehatan. Jakarta.

[Kementan] Kementerian Pertanian. 2015. Outlook Teh. http://epublikasi.setjen.pertanian.go.id/epu blikasi/outlook/2015/Perkebunan/Outlook\%20T eh\%202015/files/assets/common/downloads/O utlook\%20Teh\%202015.pdf [October $24^{\text {th }}$ 2017].

Majchrzak D, Ipsen A, Koenig J. 2015. Sucrose Replacement by rebaudioside in a model beverage. J Food Sci Technol 52: 6031-6036 DOI: 10.1007/s13197-014-1624-z.

Meriza F, Lestari DAH, Soelaiman A. 2016. Sikap dan kepuasan rumah tangga konsumen teh celup sariwangi dan sosro di Bandar Lampung. J Ilmu-IImu Agribisnis 4: 67-75.

Mihardja L, Soetrisno U, Soegondo S. 2014. Prevalence and clinical profile of diabetes mellitus in productive aged urban Indonesians. J Diabetes Inves 5: 507-512. DOI: 10.1111/jdi.12177.

Nugraha A, Sumarwan U, Simanjuntak M. 2017. Faktor determinan preferensi dan perilaku konsumen teh hitam dan hijau. J Manajemen Agribisnis 14: 198-208. DOI: 10.17358/jma.14.3. 198.

Patterson NJ, Sadler MJ, Cooper JM. 2012. Consumer understanding of sugar claims on food and drink products. Nutr Bull 37: 121-130. DOI: 10. 1111/j.1467-3010.2012.01958.x.

PureCircle Stevia Institute. 2018a. Taste of stevia. https://www.purecirclesteviainstitute.com/ingred ient-and-taste/taste-of-stevia [January $9^{\text {th }} 2019$ ].

PureCircle Stevia Institute. 2018b. Beverages. https: //www.purecirclesteviainstitute.com/ingredientand-taste/working-with-stevia-in-applications/be verages [January $9^{\text {th }} 2019$ ].

Rahmasari LF, Nurmalina R, Priatna WB. 2017. Analisis sikap, konsistensi dan kepuasan pada teh kotak ultrajaya: An experimental marketing research on IPB agribusiness master of science students. J Forum Agribisnis 7: 85-102. DOI: 10.29244/fagb.7.1.85-102.

Roy Morgan Research. 2008. An investigation into the impact of nutrition content claims on packaging in relation to consumer purchase intention, nutrition attitude and health benefits. https://www.foodstandards.gov.au/consumer/la belling/nutrition/documents/P293_Attach_10_2_ RMR.pdf [October $27^{\text {th }} 2017$ ].
Shrapnel W. 2015. Trends in sugar-sweetened beverages: Are public health and the market aligned or in conflict. Nutrients 7: 8189-8198 DOI: 10.3390/nu7095390.

Soewondo P, Ferrario A, Tahapary DL. 2013. Challenges in diabetes management in Indonesia a literature review. Globalization Health 9: 63. DOI: 10.1186/1744-8603-9-63.

Tate, Lyle. 2017a. A Functional and consumerfriendly nutritive sweetener. https://www.tateand lyle.com/sites/default/files/2017-08/Fructopure \%20Sell\%20Sheet\%20QE\%20Final\%20\%2006 0117.pdf [January $\left.9^{\text {th }} 2019\right]$.

Tate, Lyle. 2017b. Understanding beverages. https: //www.tateandlyle.com/our-expertise/beverages [January $9^{\text {th }} 2019$ ].

Tejo VK, Karsodihardjo S, Ananingsih VK. 2013. Stevia rebaudiana: An excellent natural alternative for sugar replacer. The third international congress on interdisciplinary research and development. http://www.ijcim.th.org/SpecialEdi tions/V21nSP1/02_03_25A_Vincent.pdf [October $\left.27^{\text {th }} 2017\right]$.

Thamrin I, Syarief R, Nurrcohhmat DR. 2016. Business development strategy, ready-to-drink tea, your tea, with business canvas model approach. Int J Sci Res Publication 6: 128-133.

Van Buul VJ, Tappy L, Brouns FJPH. 2014. Misconceptions about fructose-containing sugars and their role in the obesity epidemic. Nutr Res Rev 27: 119-130. DOI: $10.1017 /$ S09544224140000 67.

Verma A, Singh A. 2014. Optimization and quality assessment of low calorie herbal health tea sweetened with stevia (Stevia Rebaudiana). J Med Res Develop 3: 134-137.

Walker RW, Dumke KA, Goran MI. 2014. Fructose content in popular beverages made with and without high-fructose corn syrup. Nutr 30: 928935. DOI: 10.1016/j.nut.2014.04.003.

White JS, Hobbs LJ, Fernandez S. 2015. Fructose content and composition of commercial HFCSsweetened carbonated beverages. Int $\mathrm{J}$ Obesity 39: 176-182. DOI: 10.1038/ijo.2014.73.

[WHO] World Health Organization. 2015. Guideline: Sugar Intake for Adults and Children. WHO Document Production Services, Geneva, Switzerland.

Yolanda V, Antono L, Kurniati A. 2017. Sensory evaluation of sweet taste and daily sugar intake in normoglycemic individuals with and without family history of type 2 diabetes: A comparative cross-sectional study. Int J Diabetes Res 6: 5462. 